\title{
Application of Seismic Resisting Systems for Building Construction in Malaysia
}

\author{
Nor Baizura Hamid, Siti Noraiza Binti Ab Razak, Mohd Erwan Sanik, Mardiha Mokhtar, \\ Suhaila Sahat, Masiri Kaamin, Mohd Zakwan Ramli
}

\begin{abstract}
Over the centuries, there has been a lot of earthquakes occur due to sudden changes in the surface of the earth. This phenomenon has caused property destruction, a large number of deaths and damage to buildings. This situation has become a concern by experts, especially engineers around the world since the damage of the building caused huge losses as well as contributing to the loss of life due to burial and so forth. Therefore, this study is conducted to compare the changes of node displacement that occur in each designed buildings caused by the seismic load applied and to determine the best design system that has the smallest amount of node displacement changes during the quake. In this study, three types of model that consist of base frame, shear wall and braced frame are designed using STAAD Pro Software to obtain their displacement reading. Important data such as seismic parameters and load cases which is Zone factor: 0.24, Response reduction factor: 5, Importance factor: 1.5, Structure type: Concrete, Damping: 0.05, Foundation soil type: Medium, Dead load intensity at all floor levels: $6 \mathrm{kN} / \mathrm{m}^{2}$, Live load for roof: $1.5 \mathrm{kN} / \mathrm{m}^{2}$ and Live load for other floors: $3 \mathrm{kN} / \mathrm{m}^{2}$ are inserted. The strength of resistance toward seismic load between the three models can be evaluated through the displacement occurs in the nodes in every model.
\end{abstract}

Index Terms: Node displacement, base frame, shear wall, braced frame

\section{INTRODUCTION}

Malaysia is a country with minor seismic because it lies outside the Ring of Fire that is seen a lot of seismic activity. During structural design, the buildings in this country are mostly not be built by considering the seismic load, hence the level of safety for remains unknown. Recently, earthquake events have become more frequent and already started to be one of natural disasters occur in Malaysia especially in Sabah and Sarawak. Some earthquakes that occurred recently, such as the earthquake in Aceh, Nias, Yogyakarta and in other areas have been many casualties

Revised Manuscript Received on June 22, 2019.

Nor Baizura Hamid, Centre for Diploma Studies, Universiti Tun Hussein Onn Malaysia, Pagoh Campus, 84000 Panchor, Johor

Siti Noraiza Binti Ab Razak, Centre for Diploma Studies, Universiti Tun Hussein Onn Malaysia, Pagoh Campus, 84000 Panchor, Johor

Mohd Erwan Sanik, Centre for Diploma Studies, Universiti Tun Hussein Onn Malaysia, Pagoh Campus, 84000 Panchor, Johor

Mardiha Mokhtar, Centre for Diploma Studies, Universiti Tun Hussein Onn Malaysia, Pagoh Campus, 84000 Panchor, Johor

Suhaila Sahat, Centre for Diploma Studies, Universiti Tun Hussein Onn Malaysia, Pagoh Campus, 84000 Panchor, Johor

Masiri Kaamin, Centre for Diploma Studies, Universiti Tun Hussein Onn Malaysia, Pagoh Campus, 84000 Panchor, Johor

Mohd Zakwan Ramli, College of Engineering, Universiti Tenaga Nasional, Kajang, Selangor and property losses, including the destruction of building houses, as well as damage to public [1]. Furthermore, at least 24 earthquakes have struck Mindanao (Sunda Island) and Sulawesi which is the part of Ring of Fire with the magnitude between 4.4 and 6.0 Richter scale. Large scale of earthquake that happens nearby might also affect some areas in this country. Hence, Malaysia Meteorological Department has put Sabah on a tsunami watch since the earthquake can occur in the middle of the sea which will affect the city in north and east Sabah. They also detected a 1.2 magnitude of earthquake in Sabah at a depth of 9 kilometers $(\mathrm{km})$, with an epicenter of $13 \mathrm{~km}$ northeast of Ranau.

Besides, Peninsular Malaysia is now closer to the epicenter and will face greater impact in future quakes. Geologist have come to the conclusion that the initiation of local origin earthquake within Peninsular Malaysia is a signal of reactivation of inactive ancient faults caused by reformation of the Sundaland core [2] as illustrated in Figure 1. It is vital for engineers in Malaysia to take some precaution measures and consider them in the future building design. Thus, a decision making in designing earthquake resistant building in Malaysia is needed to help engineers to consider earthquake risk in the building design. Thus, the objective of this study are to compare the changes of node displacement that occur in each model designed caused by the seismic load applied and to determine the best design system that has the smallest value of node displacement changes during the quake.

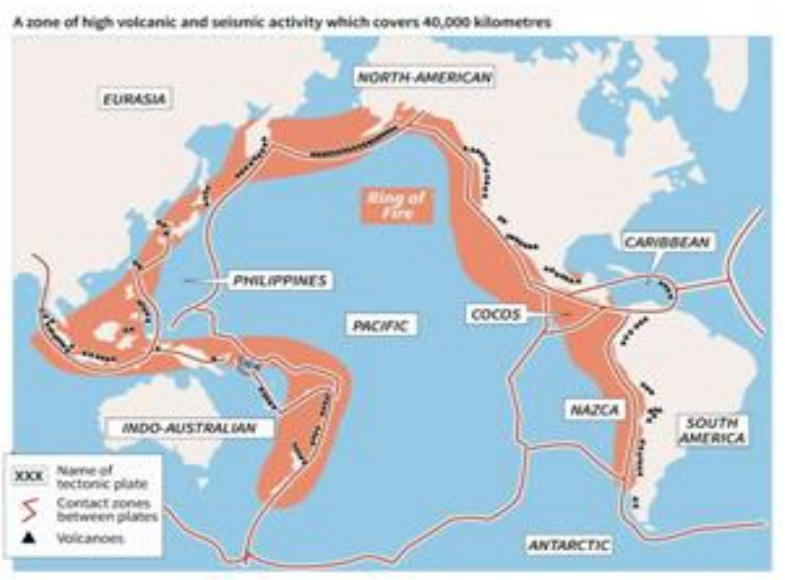

Fig. 1 Earthquake-prone region of Malaysia

\section{BACKGROUND OF STUDY}

In recent years, Malaysia has experienced the effects of earthquake originated mainly from epicenters in the western

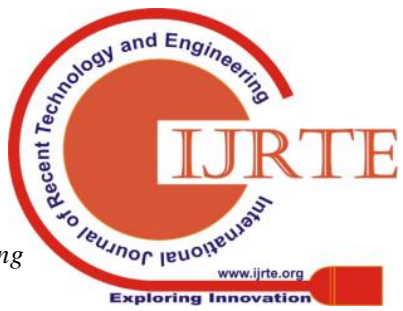


subduction zones of Sumatra [3]. East Malaysia also has its fair share of local earthquakes which are considered as moderate [3]. In 5 June 2015, the magnitude 6 earthquake which jolted the town of Ranau and Kundasang spectacularly reinforced active tectonics in Sabah [4]. Thus, the effective way of decreasing losses is to construct seismic resisting structure [5].Controlling the damage type and sequence of damage in various structural elements is the main focus of earthquake-resistant design [6]. Earthquakes caused too many damaging effects to the surrounding they act upon. This includes damage to man-made buildings structure and in worst cases the human death. The destruction of structures such as bridges, dams and buildings are caused by the rumbling impacts which originated from the earthquake. Earthquake shaking requires buildings to be capable of resisting certain relative displacement within it due to the imposed displacement at its base [6].The traditional earthquake-resistant design philosophy requires that normal buildings should be able to resist; a) Minor (and frequent) shaking with no damage to structural and nonstructural elements; (b) Moderate shaking with minor damage to structural elements, and some damage to nonstructural elements; and (c) Severe (and infrequent) shaking with damage to structural elements, but with no collapse (to save life and property inside/adjoining the building) [6].

Therefore, this study is conducted to compare the average node displacement produced in each designed model in STAAD Pro software that is caused by the seismic loads applied and to determine the best design system that able to reduce the most node displacement during the quake. Node displacement is taken for analysis of data because displacement in building design is a comprehensible tool for achieving a measure of performance in structures constructed at sites prone to earthquake shaking [7]. The displacement also becomes the first tool to be considered in selecting the basic structural system, and then the anticipated displacements are used directly as an aid in proportioning the structure and selecting details [7].

\section{A. Base Frame}

Base Frame is structural element that was designed without any additional structure system. It used to divide or enclose and in building construction. The design of the Base Frame is different compared to the other two structures; Shear Wall and Braced Frame. Its own weight, the dead load of floors and roofs, and the live load of people, as well as the lateral forces of arches, vaults and wind. It does not design as the specific structure. It used as the indicator of this study to run the analysis.

\section{B. Shear Wall}

Walls that mainly withstand lateral loads due to the wind or earthquakes acting on the building are called structural walls or Shear Wall [8]. Shear Walls provide large strength and stiffness to buildings in the direction of their orientation, which significantly reduces lateral sway of the building and thereby reduces damage to structure and its contents [9]. Provision of a Shear Wall influences the seismic performance of the structure with reference to strength and lateral displacement [10]. Shear Walls must provide the necessary lateral strength to resist horizontal earthquake forces [11].

\section{Braced Frame}

A Braced Frame is a structural system designed to resist wind and earthquake forces. It involves additional elements in order to increase the ability to withstand lateral loads to a frame one of the most suitable choices in design and improvement of reinforced concrete frames is using steel bracings [12]. Braced Frames are often used to resist lateral loads but the braces can interfere with architectural features [13]. Bracings are usually provided to increase stiffness and stability of the structure under lateral loading and also to reduce lateral displacement significantly. Earthquake ground motion may produce very large inertia forces that need to be resisted by structural element in a building [14].

\section{METHODOLOGY}

In this study, the work has started from planning the phase until the result and analysis is obtained. The planning should be organized well to make sure the work will run without difficulties and troubles also the outcome must be produced to prove the objectives stated. The data is achieved from the reading and analysis based on the existing paperwork. A few research papers and journals has been reviewed to analyze the systems and data of several building designs that create seismic resisting systems before a decision is made to choose the suitable system.

The analysis of this study uses the same value of seismic parameters, types of loads and code of practice as in a study carried by Madan et.al. The code of practice used by Madan et.al in his study is IS-1983: 2002 (Part-I). This code of practice is only used for the analysis purpose in order to obtain an output data that could be compared with [15] study as a supporting reference. After all the data has been collected, the work is preceded into the designing stage using STAAD Pro Software. In this software, the seismic parameters and load as shown in Table 1 shows the seismic parameters while Table 2 shows the load apply for create a 10 -storey building model based on the system which is Base Frame, Shear Wall and Braced Frame. Thus, the reading of the result is taken and been analyzed to plot a graph based on the node displacement changes in every model. From the graph plotted, the comparison has been made to justify the objectives of this study.

Table. 1 Seismic parameters in every model of the system

\begin{tabular}{ccc}
\hline No. & Seismic Parameters & Value \\
\hline 1 & Zone factor & 0.24 \\
2 & Response reduction factor & 5 \\
3 & Importance Factor & 1.5 \\
4 & Structure type & Concrete \\
5 & Damping & 0.05 \\
6 & Foundation soil type & Medium \\
\hline
\end{tabular}


Table. 2 Loads Assigned in every models

\begin{tabular}{ccc}
\hline No & Types of load & Value \\
\hline 1 & Dead load intensity at all floor & $6 \mathrm{kN} / \mathrm{m}^{2}$ \\
& levels & \\
2 & Live load for roof & $1.5 \mathrm{kN} / \mathrm{m}^{2}$ \\
3 & Live load for other floors & $3 \mathrm{kN} / \mathrm{m}^{2}$ \\
\hline
\end{tabular}

\section{RESULTS AND DISCUSSIONS}

In order to obtain the result and analysis, three models are designed in 10-storeyed frames using the same dimensions and materials but different type of seismic resisting System Which Is Base Frame (Without Shear Wall/Braced Frame), Shear Wall And Braced Frame. All the models are designed using the same materials as shown in Table 3 for Base Frame model while Table 4 and 5 for Shear Wall and Braced Frame respectively.

Table. 3 Materials used in Base Frame model

\begin{tabular}{cc}
\hline Materials & Size \\
\hline Beam (Concrete) & $0.35 \mathrm{~m} \times 0.60 \mathrm{~m}$ \\
Column (Concrete) & $0.55 \mathrm{~m} \times 0.55 \mathrm{~m}$
\end{tabular}

Table. 4 Materials used in Shear Wall model

\begin{tabular}{cc}
\hline Materials & Size \\
\hline Beam (Concrete) & $0.35 \mathrm{~m} \times 0.60 \mathrm{~m}$ \\
Column (Concrete) & $0.55 \mathrm{~m} \times 0.55 \mathrm{~m}$ \\
Shear Wall Thickness (Concrete) & $0.25 \mathrm{~m}$ \\
\hline
\end{tabular}

\begin{tabular}{cc}
\hline Materials & Size \\
\hline Beam (Concrete) & $0.35 \mathrm{~m} \times 0.60 \mathrm{~m}$ \\
Column (Concrete) & $0.55 \mathrm{~m} \times 0.55 \mathrm{~m}$ \\
Bracing (Concrete) & $0.4 \mathrm{~m} \times 0.4 \mathrm{~m}$ \\
\hline
\end{tabular}

After the analysis has been run in STAAD Pro Software, the displacement data in nodes that located at the corner of the building is taken and compared between the three models. The displacement values in the nodes show the resistance of every model towards seismic load. The lesser the value of the displacement produced between the models, the more effective the system used. There are 10 same numbers of nodes that has been chosen for the analysis at the same location in every design. The location of the node is shown in Figure 2. Two types of seismic load named EQX (x-direction) and EQZ (z-direction) are applied in the models. The seismic load from y-direction is not assigned in the models because the load only acts in horizontal plane which is $\mathrm{x}$ and $\mathrm{y}$ axis. Only data obtained from EQZ load will be used for comparison and analysis considering the area where the load acts in the models. Based on Figure 2, EQZ load acts at the front and back region of the building while EQX load acts at the both side of the building. EQZ load acts on a larger but thin area compared to EQX that acts on smaller but thick area of the building. Displacement can be easily observed in a thinner part in a building like at the $\mathrm{z}$-direction of the models and this is the main reason why the data from EQZ load is used.
Table. 5 Materials used in Braced Frame model

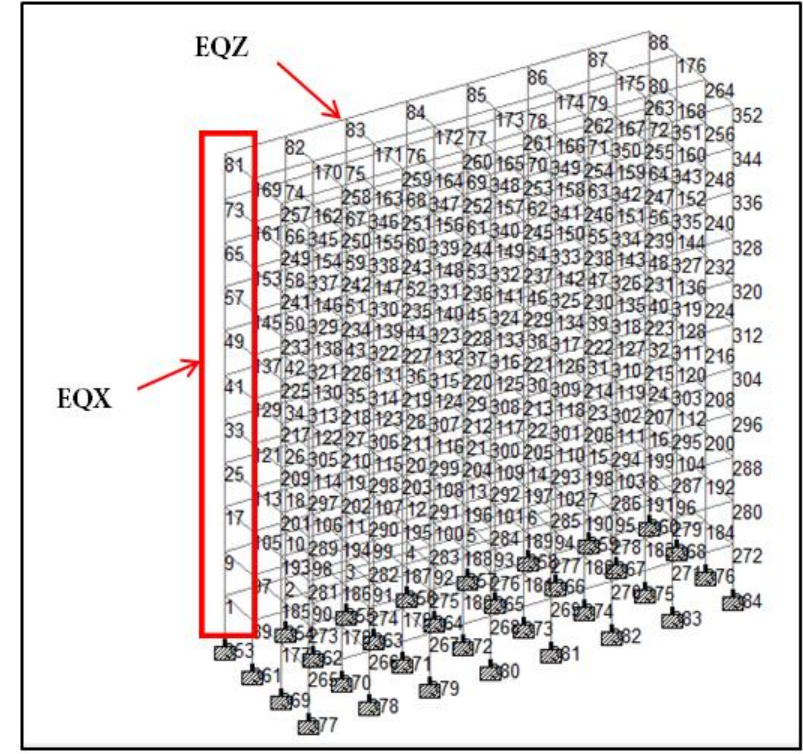

Fig. 2 Location of nodes

Table. 5 Node displacement in base frame

\begin{tabular}{ccc}
\hline NODES & EQZ (in) & EQZ (m) \\
\hline 81 & 5.361 & 0.136 \\
73 & 5.138 & 0.131 \\
65 & 4.814 & 0.122 \\
57 & 4.398 & 0.112 \\
49 & 3.908 & 0.099 \\
41 & 3.363 & 0.085 \\
33 & 2.78 & 0.071 \\
25 & 2.173 & 0.055 \\
17 & 1.558 & 0.040 \\
9 & 0.949 & 0.024 \\
\hline
\end{tabular}

Table. 6 Node displacement in shear wall

\begin{tabular}{ccc}
\hline NODES & EQZ (in) & EQZ $(\mathbf{m})$ \\
\hline 81 & 5.384 & 0.137 \\
73 & 4.919 & 0.125 \\
65 & 4.433 & 0.113 \\
57 & 3.938 & 0.100 \\
49 & 3.434 & 0.087 \\
41 & 2.929 & 0.074 \\
33 & 2.431 & 0.062 \\
25 & 1.951 & 0.050 \\
17 & 1.501 & 0.038 \\
9 & 1.101 & 0.028 \\
\hline
\end{tabular}


Table. 7 Node displacement in braced frame

\begin{tabular}{ccc}
\hline NODES & EQZ (in) & EQZ (m) \\
\hline 81 & 3.944 & 0.100 \\
73 & 3.647 & 0.093 \\
65 & 3.318 & 0.084 \\
57 & 2.963 & 0.075 \\
49 & 2.585 & 0.066 \\
41 & 2.191 & 0.056 \\
33 & 1.792 & 0.046 \\
25 & 1.402 & 0.036 \\
17 & 1.04 & 0.026 \\
9 & 0.731 & 0.019 \\
\hline
\end{tabular}

From the data obtained, the node displacement average values in each design are calculated and a graph of node displacement versus number of node is plotted as in Figure 3. From the graph and comparison of average node displacement in Table 8, it can be concluded that compared to average node displacement in the base frame model with average $0.875 \mathrm{~m}$, structure with braced frame has reduced more node displacement than structure with shear wall with average $0.814 \mathrm{~m}$ and 0.601 respectively. This output shows that based on this design, braced frame is better than shear wall in reducing and resisting the seismic load.

Table. 8 Comparison of displacement

\begin{tabular}{cccc}
\hline Nodes & Base Frame & Shear Wall & Braced Frame \\
\hline $\mathbf{9}$ & 0.024 & 0.028 & 0.019 \\
$\mathbf{1 7}$ & 0.04 & 0.038 & 0.026 \\
$\mathbf{2 5}$ & 0.055 & 0.05 & 0.036 \\
$\mathbf{3 3}$ & 0.071 & 0.062 & 0.046 \\
$\mathbf{4 1}$ & 0.085 & 0.074 & 0.056 \\
$\mathbf{4 9}$ & 0.099 & 0.087 & 0.066 \\
$\mathbf{5 7}$ & 0.112 & 0.1 & 0.075 \\
$\mathbf{6 5}$ & 0.122 & 0.113 & 0.084 \\
$\mathbf{7 3}$ & 0.131 & 0.125 & 0.093 \\
$\mathbf{8 1}$ & 0.136 & 0.137 & 0.1 \\
\hline Average & 0.875 & 0.814 & 0.601 \\
\hline
\end{tabular}

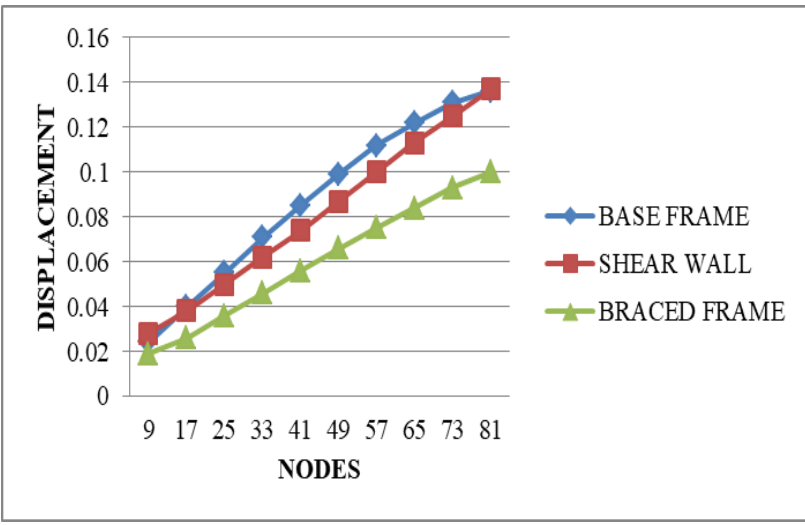

Fig. 3 Displacement versus Nodes

Model with braced frame show the least node displacement average among the models because it resulted in lesser member forces and floor displacements [3]. Braces raise lateral stiffness and dissipate considerable amount of energy during earthquake loading and the shear is primarily absorbed by the diagonal braces as axial load, thereby creating an efficient structural system [3]. A substantial increase in the shear resisting capacity of concrete frames could also be achieved using diagonal steel X-bracing [3]. All of these factors justify the reason for the average value obtained from model with braced frame which contribute in creating braced frame itself stiffer and more suitable to be used as an effective seismic-resistant system.

\section{CONCLUSION}

At the beginning of this study, a few research papers have been reviewed to gather important information and data to be used and compared in this study as references. Through the analysis that has been done in STAAD Pro Software, the output data of average node displacements in each model are compared in order to achieve the first objective of this study which is to compare the changes of node displacement due to seismic load between the three models. Madan et.al saidshear walls and braced frames have improved the seismic performance of frames. He also concludes in his study that the braced frame system has reduced the maximum displacement in the same design of frames [3]. Hence, based on the average node displacement data in this study, it is proven that shear walls and braced frames do improve the seismic performance of a frames or building. Between the two seismic-resisting systems, braced frame has reduced the most node displacement compared to shear wall.

As a conclusion, the results of analysis in this study match the conclusion made by Madan et.al [3]. However, this similarity is not always valid for all types of designs. The node displacement in every design actually depends on the design of the building itself and also the materials used in the design. Through the conclusion that has been made, the second objective of this study has been achieved since the models with braced frame has shown the best resistance towards seismic load compared to model with base frame and shear wall as the model recorded the smallest amount of node displacement after the quake. The smaller the displacement recorded in a structure during an earthquake, the stiffer the condition of the building. Therefore, for analysis in this study, braced frame contributes most additional strength and support towards seismic performance in the structure followed by shear wall.

\section{ACKNOWLEDGMENT}

This study was sponsored by theMinistry of Education Malaysia through FRGS grant (Vot No.:1620). The author would like to thank to Research Management Centre (RMC), UTHM, Johor. The extended gratitude to Asummul Khairiah Aspar, Najihah Abd Rahman and Siti Fatimah AzZahrak Mohd Shukri for accomplished this study. 


\section{REFERENCES}

1. Endah Wahyuni (2015). "Vulnerability Assessment of Reinforced Concrete Building Post-

2. Earthquake," 2nd International Seminar on Ocean and Coastal Engineering, Environment and Natural Disaster Management, ISOCEEN.

3. Fauziah Kassim, A. Marto, C.S. Tan, N. Z. M. Yunus (2013), "Seismic Impact In Peninsular Malaysia," The 5th International Geotechnical Symposium-Incheon, pp. 22-24.

4. Dr. Jeffrey Chiang and M. C. Hee (2008). Technical Review of JKR's "Handbook on Seismic Design Guidelines for Concrete Buildings in Malaysia. Jurutera. Seismic Guidelines Malaysia. pp.26-28

5. Felix Tongkul (2016). The 2015 Ranau Earthquake: Cause and Impact. Sabah Society Journal, 32, pp.1-28

6. Sameh A. El-Betar. (2016). Seismic Vulnerability Evaluation of Existing R.C. Buildings. Housing and Building National Research Center HBRC Journal.14, 189-197.

7. C.V.R. Murty, Rupen Goswami, A. R. Vijayanarayanan and Vipul V. Mehta (2012). Some Concepts in Earthquake Behaviour of Buildings. Gujarat State Disaster Management Authority, Government of Gujarat.

8. Jack P. Moehle (2013). Displacement-Based Seismic Design Criteria. Eleventh World Conference on Earthquake Engineering. Richmond, USA: Paper No.2125

9. Ali Kaveh and Pooya Zakian (2014).Optimal Seismic Design of Reinforced Concrete Shear Wall-Frame Structures. KSCE Journal of Civil Engineering. 18(7), 2181-2190.

10. M.D Kevadkar and P. B. Kodag (2013). Lateral Load Analysis of R.C.C. Building. International Journal of Modern Engineering Research (IJMER). 3(3), 1428-1434.

11. Dr. K. V. G. Balaji and K. Lova Raju (2015). Effective location of Shear Wall on performance of building frame subjected to earthquake load. International Advanced Research Journal in Science, Engineering and Technology. 2(1).

12. Timothy P. McCormick (2009). P.E, Seismic Retrofit Training. ABAG, The Association of Bay Area Governments. 2(1).

13. Massumi and Absalan (2013). Interaction Between Bracing System And Moment Resisting Frame In Braced RC Frames. Archives of Civil and Mechanical Engineering. 2013. 13(2):260-268.

14. Zasiah Tafheem and Shovona Khusru (2015). Structural behavior of steel building with concentric and eccentric bracing: A comparative study. International Journal Of Civil And Structural Engineering. 6(2), 140-147.

15. Dhananjay. S. Pawar, S. Abdulla U. Phadnis, Raju. S. Shinde, Yugandhar. N. Jinde (2015). Analysis of multistoried Braced Frame subjected to seismic and gravity loading. International Journal of Engineering Research and Applications. ISSN : 2248-9622, 5(3), pp. 46-50.

16. S. K. Madan, R. S. Malik, V. K. Sehgal (2015). Seismic Evaluation with Shear Walls and Braces for Buildings. World Academy of Science, Engineering and Technology International Journal of Computer and Information Engineering, Vol 9. 